\title{
POSITIONING OF FERTILIZER IN CORN SOWING
}

\section{PEDRO H. WEIRICH NETO ${ }^{1}$, ALTAIR JUSTINO ${ }^{2}$, IVO FRARE ${ }^{3}$, JORGE N. GOMES ${ }^{4}$, LUIZ C. GARCIA ${ }^{5}$}

\begin{abstract}
The aim of this study was to determine whether the form of placing the fertilizer by the planter during the sowing under mulch in the no till system affects the yield of corn. The treatments consisted of placing the fertilizer during the seeding $0.05 \mathrm{~m}$ below and beside the seed, in front of the cutting blade and without fertilizer, in 03 farms during 03 cropping years. The experimental design at each farm was the randomized block, with 08 repetitions, whose plots had $30 \mathrm{~m}^{2}$ each. The initial population and yield components were evaluated. Under the experimental conditions it is concluded that base fertilization can affect the yield. Fertilizer placement can affect the initial stand, but not the yield.
\end{abstract}

KEYWORDS: tillage, seeding fertilizer, yield components.

\section{POSICIONAMENTO DO ADUBO NA SEMEADURA DO MILHO}

RESUMO: O objetivo deste trabalho foi verificar se a forma de colocação de adubo pela semeadora adubadora na instalação da cultura, em sistema de semeadura direta sob a palha, afeta os componentes de rendimento da cultura do milho. Os tratamentos consistiram na colocação do adubo 0,05 m abaixo e ao lado da semente, na frente do disco de corte e sem adubo na semeadura, em 03 propriedades e em 03 anos agrícolas. Em cada propriedade, o delineamento experimental adotado foi o em blocos ao acaso, com 08 repetições, cujas parcelas possuíam $30 \mathrm{~m}^{2}$ cada. Avaliaram-se a população inicial e os componentes de rendimento. Nas condições experimentais, conclui-se que a adubação na base pode afetar os componentes de rendimento. O posicionamento do adubo pode afetar o estande inicial, mas não os componentes de rendimento.

PALAVRAS-CHAVE: plantio direto, semeadora adubadora, componentes de rendimento.

\section{INTRODUCTION}

Seed quality is a major factor for the success of cultures that is reflected later in productivity. So much has been done to evaluate the quality of the seed; however, little has been studied on the effects of cultural practices on the physiological quality (Azevedo et al. 2007).

Among the factors that affect the increase in corn yields are population and fertilization (EMBRAPA, 2010). CASÃO JR et al. (1997), GARCIA et al. (2006) and WEIRICH NETO et al. (2007) state that in the no-tillage fertilizer seeder performs both functions, and should be able to cut without moving the mulch, open grooves with little tilling soil, prevent soil adhesion to components, have good penetration, control depth, depositing fertilizer regularly and seed distant enough to avoid the salt effect, regular distribution of seeds, cover and compacting the soil on the seeds.

According to Oliveira et al. (2003) and Almeida et al. (2008) the superficial soil compaction is a strong restriction on tillage, where the use of rod type furrow openers on planters have become widespread as an alternative to break it. ANDREOLLA GABREIL \& SON (2006) and CONTE et

\footnotetext{
${ }^{1}$ Engenheiro Agrícola, Professor Doutor, Universidade Estadual de Ponta Grossa - PR, Departamento de Ciências do Solo e Engenharia Agrícola, Fone: (042) 3220 3092, lama1@uepg.br.

${ }^{2}$ Engenheiro Agrônomo, Prof. Dr., Universidade Estadual de Ponta Grossa - PR, Depto. de Ciências do Solo e Engenharia Agrícola.

${ }^{3}$ Administrador, Gerente técnico da Fazenda Mutuca, Arapoti - PR.

${ }^{4}$ Engenheiro Agrônomo, Forterra, Tibagi - PR.

${ }^{5}$ Engenheiro Agrônomo, Prof. Dr., Universidade Estadual de Ponta Grossa - PR, Depto. de Ciências do Solo e Engenharia Agrícola. Recebido pelo Conselho Editorial em: 10-11-2011

Aprovado pelo Conselho Editorial em: 30-6-2013
} 
al. (2007) argue that the stems form the seed furrows with depths larger than the double disc, with consequent increase of tillage, and traction power requirement in tractors. . FURLANI et al. (2007) points out that soil moisture at sowing time affects the force on the drawbar, the same adherence to the implement, opening and closing of the furrow. In sloped areas and large amount of mulch, Aratani et al. (2006) found that the distance between the blade and the fertilizer furrow openers and seed can provide points of mulch accumulation in the process of sowing tillage system.

CONUS et al. (2009) emphasized that the improper placement of the fertilizer may often cause problems in the emergence of seeds, since the fertilizer has a salt effect on the soil, the seed competing with the seed in the absorption of moisture. For SILVA et al. (2000) fertilization performed at $0.1 \mathrm{~m}$ depth, provided increased plant stands, number of spikes per meter and were responsible for high grain yields in relation to the placement of the fertilizer to $0.05 \mathrm{~m}$. SANGOI et al. (2009) concluded that the application of nitrogen fertilizer at planting in furrows, $0.05 \mathrm{~m}$ deep and $0.03 \mathrm{~m}$ away from the seed, lowered germination of maize in four of the five soils evaluated.

Studying the position of phosphorus and potassium fertilization on the seed and seedling growth of corn, BEVILAQUA et al. (1996) concluded that the position of the fertilizer that provides higher dry matter, percentage and emergence rate was between 0.05 and $0.06 \mathrm{~m}$ beside and below the seed. The potassium fertilizer shows damaging effect on maize seedlings, primarily in positions closest to seed.

The aim of this study was to determine whether the form of the placement of fertilizer seeder fertilizer in crop installation in no-tillage under the mulch affects yield components of maize.

\section{MATERIAL AND METHODS}

The experiment was conducted in three distinct properties and crop years. The properties are located in the region of Campos Gerais, Paraná State, Brazil located at coordinates $25^{\circ} 16^{\prime \prime}$ south latitude and $50^{\circ} 16^{\prime \prime}$ west longitude, climate $\mathrm{Cfb}$ in direct seeding system under the mulch over 25years. Crop years were 2007/08, 2008/09 and 2009/10. The rainfall covering the period in which the corn crop was in the field during three years is detailed in Figure 1, with averages of data collected by rain gauges on properties where the experiment was conducted.

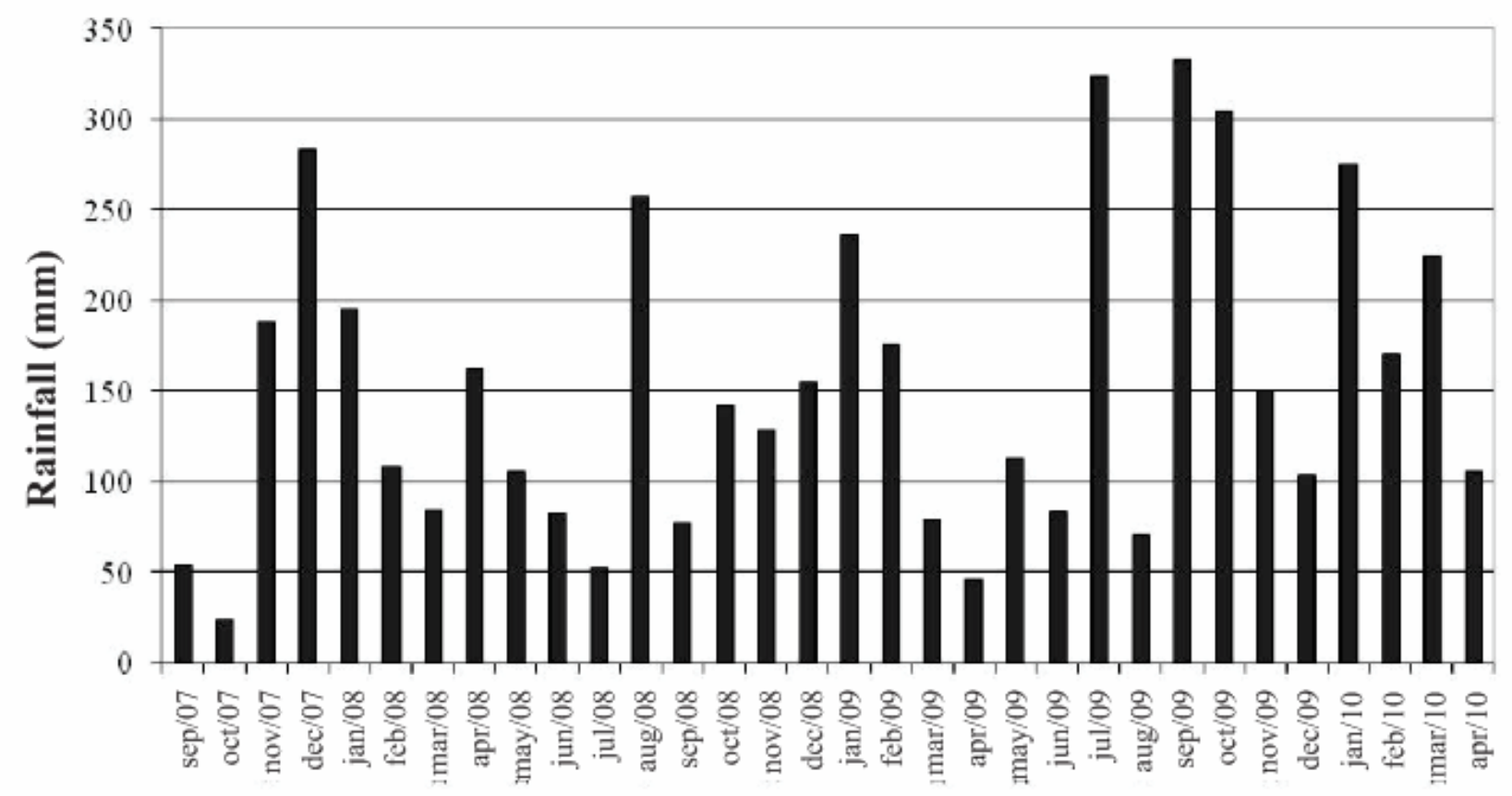

FIGURE 1. Rainfall in the region of Campos Gerais - PR from August 2007 to April 2010.

The Property "A" is located in Arapoti - PR, with $960 \mathrm{~m}$ of altitude and Red Latosol eutrophic. Fertilization at sowing was $250 \mathrm{~kg} \mathrm{ha}^{-1}$ of the mix 18-36-00 NPK granules. Sowing of 
hybrid Pioneer 30R50 ${ }^{\circledR}$ under $7.4 \mathrm{t} \mathrm{ha}^{-1}$ of wheat mulch harvested that occurred on September 28, 2007 with 75,000 seeds per hectare. It was used a tractor CBT ® Model 8060 to $73.5 \mathrm{~kW}$ (100 hp). The planter fertilizer was Semeato ${ }^{\circledR}$ SSM 27, equipped with six units of seeding, spaced apart by $0.80 \mathrm{~m}$, with a system of perforated horizontal plate of 28 holes, flat blade about $0.36 \mathrm{~m}$ diameter furrow openers fertilizer type "knife" with ferrules to $0.025 \mathrm{~m}$ width and angle of attack of $20^{\circ}$ (guillotine) and opening mechanism of the seed furrow with offset double disc of $0.33 \mathrm{~m}$ in diameter.

The property "B" is located in Pirai do Sul, with $910 \mathrm{~m}$ of altitude and Dystrophic Red Yellow Latosol. Fertilization at sowing was $200 \mathrm{~kg} \mathrm{ha}^{-1}$ of diammonium phosphate (DAP). There were at the time of seeding $5.1 \mathrm{t} \mathrm{ha}^{-1}$ of oat mulch, dried with $2.0 \mathrm{~L}$ of glyphosate 45 days before crop establishment and handled mechanically 30 days before planting Pioneer $₫$ hybrid 30P34that occurred on 16 September 2008, with 70,000 seeds per hectare. . The tractor used was the John Deere ${ }^{\circledR} 7500$ - $103 \mathrm{~kW}(140 \mathrm{hp})$. The seeder fertilizer was used pneumatic SLC ${ }^{\circledR}$ 913, with seven units seeding, spaced at $0.80 \mathrm{~m}$, with 30 holes of vertical disc, disc smooth cut of $0.36 \mathrm{~m}$ in diameter, the type of fertilizer furrowers "knife" with ferrules to $0.025 \mathrm{~m}$ width and angle of attack of $20^{\circ}$ (guillotine), opening mechanism of the seed furrow with offset double disc of $0.33 \mathrm{~m}$ in diameter and groove closure with wheels double-angled "V "0.30 m.

The property "C" is located at Tibagy - PR, with 1,040 m of altitude and a Yellow Ox soil Entropic. Fertilization at sowing was $300 \mathrm{~kg} \mathrm{ha}^{-1}$ mixture of granules NP 15-30-00. There were at the time of seeding $4.5 \mathrm{t} \mathrm{ha}^{-1}$ of oat straw, dried with $2.0 \mathrm{~L}$ of glyph sate 40 days before crop establishment and rolled 20 days before planting Pioneer ${ }^{\circledR}$ hybrid 30F53, since that occurred on 26 September 2009, with 80,000 seeds per hectare. The tractor was used Massey Ferguson ${ }^{\circledR}$ model 292 to $77.2 \mathrm{~kW}(105 \mathrm{hp})$. The seeder was Semeato ® SSM 27, equipped with six sowing units, spaced at $0.80 \mathrm{~m}$, with perforated horizontal plate of 28 holes, flat blade diameter of $0.36 \mathrm{~m}$, the fertilizer furrow openers offset double disc-type $0.33 \mathrm{~m}$ diameter opening mechanism seed furrow with offset double disc diameter of $0.33 \mathrm{~m}$ and closing wheels with double-angled "V" $0.30 \mathrm{~m}$.

All planters were regulated so that the seed was distributed to $0.05 \mathrm{~m}$ depth. The deposits of fertilizer and seed were supplied with $50 \%$ of its volumetric capacity. All seeds of maize were above $95 \%$ germination and below $1 \%$ impurity. Sowing was performed with friable soil, being the average water content in the soil layer from zero to $0.1 \mathrm{~m}$ was around $30 \%$. The seeding rate did not exceed $6.0 \mathrm{~km} \mathrm{~h}^{-1}$.

The fertilization in the base and cover followed the agronomic recommendations based on chemical analysis of the properties of soils (Table 1). Based on studies BEVILAQUA et al. (1996) and chemical analysis of soils technicians from farms not recommend applying potassium fertilizer at sowing. The control of weeds, pests and diseases followed the patterns of agricultural properties. Crops on 03 different crop years were held in the months of March and April.

TABLE 1. Chemical analysis of soil, $0-20 \mathrm{~cm}$, the properties in which the experiment was conducted, the region of Campos Gerais - PR.

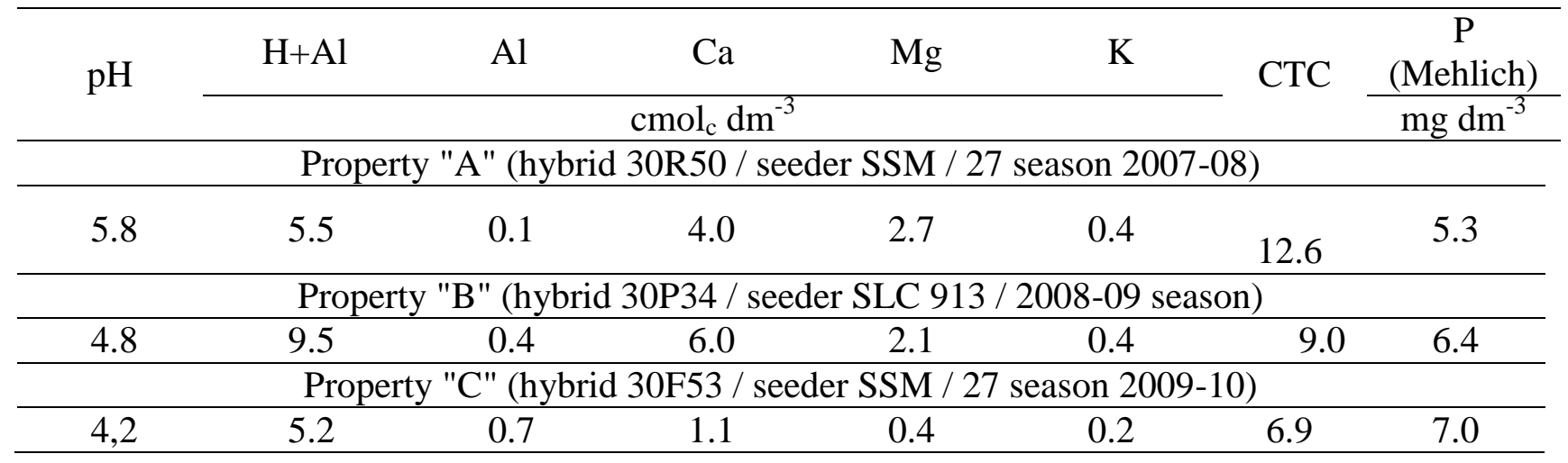


In each farm, the experimental design was a randomized block with three treatments. Treatments consisted on fertilizer distribution $0.05 \mathrm{~m}$ beside and below the seed on the surface and in front of the blade (Figure 2) and no fertilizer at sowing in 08 replicates per treatment. Treatment with fertilizer placed in front of the blade systems opening groove for fertilizer and seed were aligned. The plot area of $30 \mathrm{~m} 2$ was evaluated.

The variables evaluated were: initial population (20 days after emergence, DAE), number of ears per hectare (15 days before harvest), grains per spike, thousand grain weight and yield.

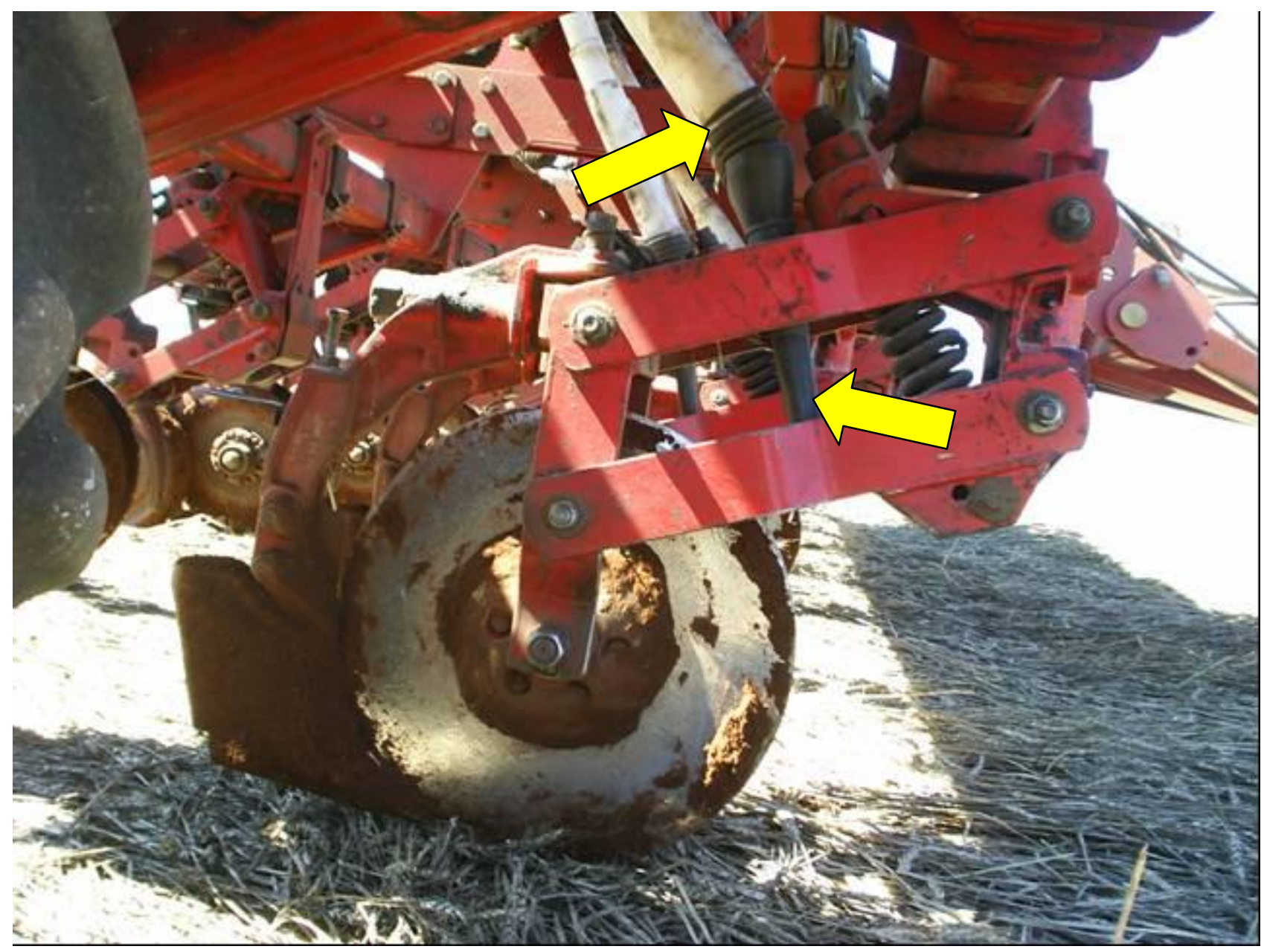

FIGURE 2. Sower fertilize with fertilizer distribution in front of the cutting disk tillage under the mulch in the region of Campos Gerais - PR.

The harvesting, threshing, counting grains per spike and thousand grain weight were performed manually. The determination of the thousand grain weight and yield occurred with 1.0\% of impurities and moisture corrected to $14.5 \%$ wb (CLASPAR, 2011). Moisture was found with the use of a moisture meter (G800 Gehaka $®)$. The weight of a thousand grains was determined by means of a digital scale Diamond $®(0.1$ to $500 \mathrm{~g})$.

The Hartley test was applied for verifying homoscedasticity of variances. The variables were tested with F and Duncan.

\section{RESULTS AND DISCUSSION}

The Hartley test indicated the homoscedasticity of variances for all variables studied. So there was no need for transformation of the means for applying the $\mathrm{F}$ test. There were significant differences only for the blocks in the variable "seedling" in 02 properties (Table 2), indicating the homogeneity of the experimental conditions. 
The results of the experiment confirmed the claims of Azevedo et al. (2007) and EMBRAPA (2010), since the corn yield was significantly affected by fertilization in 02 properties. When analyzing the data, it found that a lack of fertilizer at the base can affect the number of spike per hectare and the number of grains per spike. The exception occurred on the property "A".

Treatments alter important functions of the seeding fertilizer at sowing, listed by Casão JR et al., (1997), Garcia et al. (2006) and WEIRICH NETO et al. (2007). With the placement of fertilizer below and to the side of the seed - reducing the possibility of enhancing the salt effect and deepening the roots of maize seedlings - it increases the probability of fertilizer and seed lines do not follow the cut straw. Thus, according to assert Oliveira et al. (2003), ANDREOLLA GABREIL \& SON (2006), Aratani et al. (2006), CONTE et al. (2007) and Almeida et al. (2008), there may be greater soil area mobilized, bushings, grip ground to machine components, lower penetration, seed and fertilizer placement irregular and insufficient compaction of soil over the seeds.

TABLE 2. Yield components of maize (Zea mays L.) deployed in the region of Campos Gerais (PR) in tillage under the mulch, with different placement of fertilizer at sowing, on 03 properties and 03 different crop years.

\begin{tabular}{|c|c|c|c|c|c|}
\hline $\begin{array}{l}\text { TREATMENTS (PLACEMENT } \\
\text { OF FERTILIZER AT SOWING) }\end{array}$ & $\begin{array}{l}\text { seedlings } \\
\text { (ha) }\end{array}$ & $\begin{array}{l}\text { SPIKES } \\
\text { (ha) }\end{array}$ & $\begin{array}{l}\text { Grainper } \\
\text { spike }\end{array}$ & $\begin{array}{l}\text { Weigth } \\
\text { grains } \\
(\mathrm{g})\end{array}$ & $\begin{array}{l}\text { productivity } \\
\left(\mathrm{kg} \mathrm{ha}^{-1}\right)\end{array}$ \\
\hline \multicolumn{6}{|c|}{ Property "A" (hybrid 30R50 / seeder SSM / 27 season 2007-08) } \\
\hline $\begin{array}{l}\text { 0.05M BESIDE AND BELOW } \\
\text { THE SEED }\end{array}$ & $72,100 \mathrm{a}^{1}$ & $71,000 \mathrm{a}$ & $541 \mathrm{a}$ & $337 \mathrm{a}$ & 12,864 a \\
\hline in front of the cutting disc & $72,400 \mathrm{a}$ & $71.100 \mathrm{a}$ & $561 \mathrm{a}$ & $311 \mathrm{a}$ & $12.349 \mathrm{a}$ \\
\hline $\begin{array}{l}\text { WITHOUT FERTILIZER AT } \\
\text { SOWING }\end{array}$ & 73,250 a & $70.400 \mathrm{a}$ & $553 \mathrm{a}$ & $336 \mathrm{a}$ & $13.163 \mathrm{a}$ \\
\hline BLOCKS & $\mathrm{ns}^{2}$ & ns & ns & ns & ns \\
\hline $\mathrm{CV}(\%)$ & 2,2 & 3,2 & 5,4 & 10,9 & 8,7 \\
\hline \multicolumn{6}{|c|}{ Property "B" (hybrid 30P34 / seeder SLC 913 / 2008-09 season) } \\
\hline $\begin{array}{c}0.05 \text { M BESIDE AND BELOW } \\
\text { THE SEED }\end{array}$ & $66.500 \mathrm{a}$ & $61.250 \mathrm{a}$ & $494 \mathrm{a}$ & $241 \mathrm{a}$ & $7215 \mathrm{a}$ \\
\hline in front of the cutting disc & $66.250 \mathrm{a}$ & $59.625 \mathrm{a}$ & $506 \mathrm{a}$ & $242 \mathrm{a}$ & $7.313 \mathrm{a}$ \\
\hline $\begin{array}{l}\text { INTO FERTILIZER AT } \\
\text { SOWING }\end{array}$ & $65.438 \mathrm{a}$ & $61.188 \mathrm{a}$ & $392 \mathrm{~b}$ & $250 \mathrm{a}$ & $5.956 \mathrm{~b}$ \\
\hline BLOCKS & $*^{3}$ & ns & ns & ns & ns \\
\hline $\mathrm{CV}(\%)$ & 2.1 & 3.6 & 6.6 & 11.8 & 6.4 \\
\hline \multicolumn{6}{|c|}{ Property "C" (hybrid 30F53 / seeder SSM / 27 season 2009-10) } \\
\hline $\begin{array}{l}\text { 0.05M BESIDE AND BELOW } \\
\text { THE SEED }\end{array}$ & $74,286 \mathrm{~b}$ & $72,589 \mathrm{a}$ & $505 \mathrm{a}$ & $346 \mathrm{a}$ & $12,631 \mathrm{a}$ \\
\hline in front of the cutting disc & $77,232 \mathrm{a}$ & $72,232 \mathrm{a}$ & $515 \mathrm{a}$ & $342 \mathrm{a}$ & $12,732 \mathrm{a}$ \\
\hline $\begin{array}{l}\text { WITHOUT FERTILIZER AT } \\
\text { SOWING }\end{array}$ & $77,500 \mathrm{a}$ & $68,929 \mathrm{~b}$ & $419 \mathrm{~b}$ & $347 \mathrm{a}$ & $9,984 \mathrm{~b}$ \\
\hline Blocks & $*$ & ns & ns & ns & $\mathrm{ns}$ \\
\hline $\mathrm{CV}(\%)$ & 1.9 & 3.7 & 13.9 & 7.7 & 14.4 \\
\hline
\end{tabular}

1 - Means followed by the same letter in the column do not differ significantly by Duncan's test (P> .05). 2 - Not significant by F test (P> .05). 3 - Significant by F test (P> .05).

In property " $\mathrm{C}$ " positioning of the fertilizer to the side and below the seed significantly reduced the number of seedlings per hectare, but did not affect yield components, contradicting assertions SILVA et al. (2000).

With the fertilizer spread in front of the cutting disc and distribution systems fertilizer and seed aligned on the chopped straw, one can reduce the bushing decrease the removal of soil and 
straw, to improve penetration depth control and achieve good distribution of fertilizer and seeds. Compost positioned in front of the cutting disc is acted the same, the system of placing fertilizer and seed, being mixed in the soil, avoiding - as claimed CONUS et al. (2009) SANGOI et al. (2009) the formation of a row of fertilizer could potentiate the effect of saline. These assumptions were confirmed in the experiment since the fertilizer placed in front of the blade not present in all variables, significant differences disadvantageous when compared with the fertilizer placed $0.05 \mathrm{~m}$ below and beside the seed without fertilization at sowing (Figure 3).

The absence of fertilization on the basis of property " $\mathrm{C}$ " with Latosol yellow eutrophic provided higher number of seedlings that the positioning of the fertilizer $05 \mathrm{~cm}$ beside and below the seed. The results show the importance of salt effect mentioned by CONUS et al. (2009) SANGOI et al. (2009); contrary, however, claims SILVA et al. (2000), which is not recommended for distribution of fertilizer on the soil surface.

It is observed in Figure 01 the variation of rainfall in the years in which the experiment was at field with water deficit at sowing in 2007, normality conditions in September 2008 and heavy rainfall in the installation of culture in 2009. As treatments have changed settings of seeders, experienced the situations mentioned by field ANDREOLLA GABREIL \& SON (2006), AZEVEDO et al. (2007), CONTE et al. (2007) FURLANI et al. (2007), in the period covered by the experiment. In agricultural years, properties and management forms the results were similar, with the placement of fertilizer at sowing not interfering in yield components of maize.

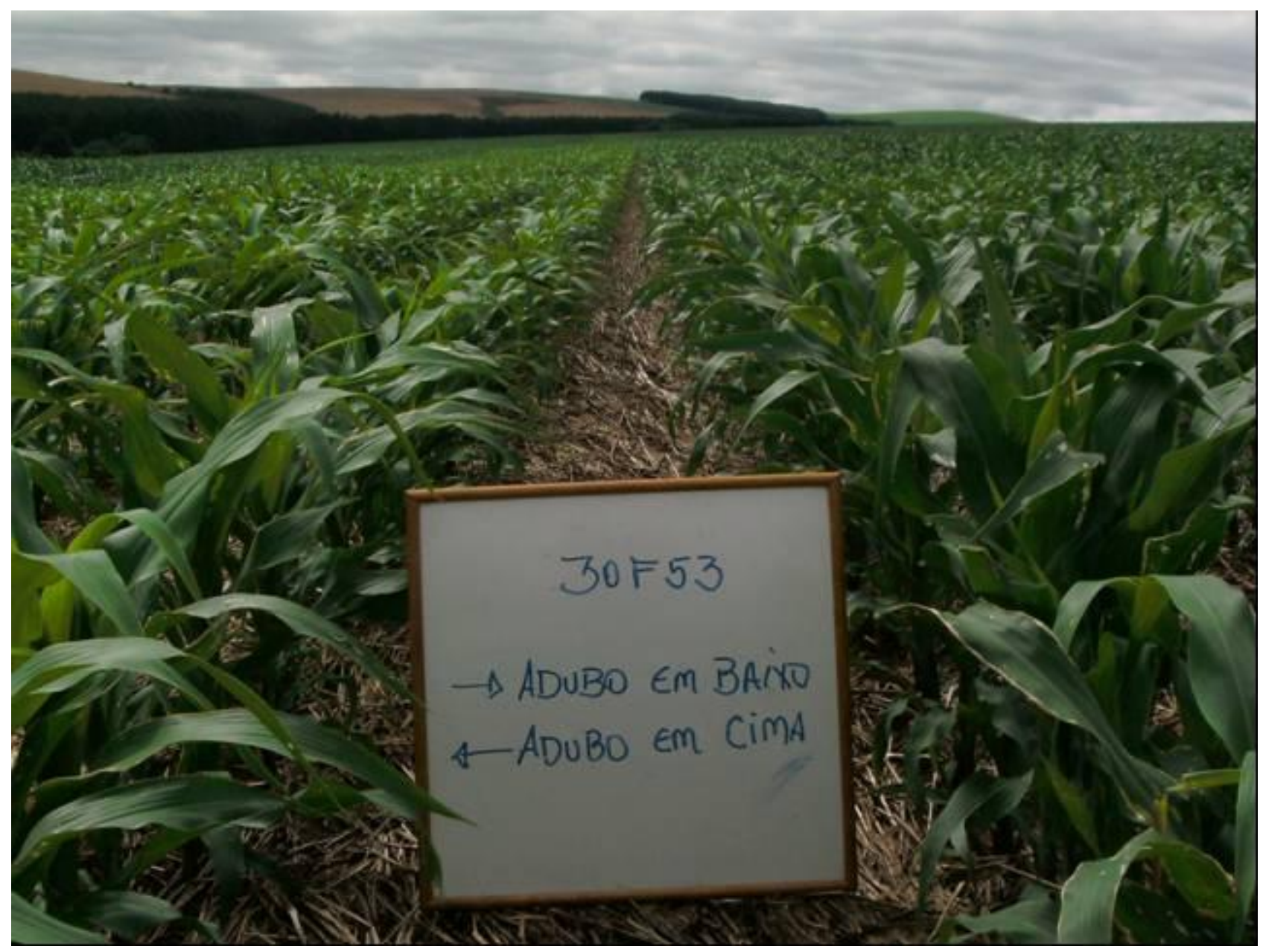

FIGURE 3. Different placements of fertilizer at sowing of maize (Zea mays L.) deployed in the region of Campos Gerais (PR), under the mulch of oat (Avena strigosa $\mathrm{S}$ ). 


\section{CONCLUSIONS}

Under the experimental conditions we conclude that base fertilization can affect the yield components. Lack of fertilizer at the base can benefit seedling emergence, but reduce the number of spikes per acre, the number of grains per spike and productivity.

The placement of the fertilizer $0.05 \mathrm{~m}$ beside and below the seed or in front of the blade does not significantly alter yield components.

\section{REFERENCES}

ALMEIDA, V.P.; ALVES, M.C.; SILVA, E.C.; OLIVEIRA, S.A.. Rotação de culturas e propriedades físicas e químicas em Latossolo Vermelho de Cerrado sob preparo convencional e semeadura direta em adoção. Revista Brasileira de Ciência do Solo, Viçosa-MG, v.32, n. 03. p. $1.227-1.237,2008$.

ANDREOLLA, V.R.M.; GABREIL FILHO, A. Demanda de potência de uma semeadora com dois tipos de sulcadores em áreas compactadas pelo pisoteio de animais no sistema integração lavourapecuária. Engenharia Agrícola, Jaboticabal, vol.26, n.3, p. 768-776, 2006.

ARATANI, R.G.; MARIA, I.C.; CASTRO, O.M.; PECHE FILHO, A.; DUARTE, A.P.; KANTHACK, R.A.D. Desempenho de semeadoras-adubadoras de soja em Latossolo Vermelho muito argiloso com palha intacta de milho. Revista Brasileira de Engenharia Agrícola e Ambiental, Campina Grande, v.10, n.2, p. 517-522, 2006.

AZEVEDO, M. P.; LEITE, L.F.C.; TEIXEIRA NETO, M.L., DANTAS, J.S. Atributos físicos e químicos de um Latossolo Amarelo e distribuição do sistema radicular da soja sob diferentes sistemas de preparo no cerrado maranhense. Revista Ciência Agronômica, Fortaleza, v. 38, n.1, p.32-40, 2007.

BEVILAQUA, G.A.P.; BROCH, D.L.; POSSENTI, J.C. ; VILLELA, F.A. Posição do fósforo e potássio na adubação da semente e no crescimento de plântulas de milho. Revista Brasileira de Agrociência, Pelotas, v. 2, n. 2, p.87-92, 1996.

CASÃO JUNIOR, C; ARAÚJO, A.G.A.; MEDEIROS, G.B.; CASTRO FILHO, C.; DORETTO, M.; FIGUEIREDO, P.R.A.; CAVIGLIONE, J. H. Viabilização da mecanização do sistema de plantio direto nos municípios à margem da represa Itaipu. Londrina: IAPAR, 1997. 32 p.

CLASPAR. Produtos padronizados: milho, 2011. Disponível em:

<http://www.claspar.pr.gov.br/arquivos/File/pdf/milho11_96.pdf>. Acesso em: 29 abr. 2011.

CONTE, O.; LEVIEN, R.; TREIN, C.R.; CEPIK, C.T.C.; DEBIASI, H. Demanda de tração em haste sulcadora na integração lavoura-pecuária com diferentes pressões de pastejo e sua relação com o estado de compactação do solo. Engenharia Agrícola, Jaboticabal, v. 27, n.1, p. 220-228, 2007.

CONUS, L.A.; CARDOSO, P.C.; VENTUROSO, L.R.; SCALON, S.P.Q. Germinação de sementes e vigor de plântulas de milho submetidas ao estresse salino induzido por diferentes sais. Revista Brasileira de Sementes, Viçosa-MG, v. 31, n. 4, p. 67-74, 2009.

EMBRAPA. Sistema de produção do milho, 2010. Disponível em:

<http://www.cnpms.embrapa.br/publicacoes/milho_6_ed/plantio.htm>. Acesso em: 15 abr. 2011.

FURLANI, C.E.A.; PAVAN JÚNIOR, A.; LOPES, A.; SILVA, R.P.; GROTTA, D.C.C.; CORTEZ, J.W. Desempenho operacional de semeadura-adubadora em diferentes manejos da cobertura e da velocidade. Engenharia Agrícola, Jaboticabal, v. 27, n.2, p. 456-462, 2007.

GARCIA L. C.; JASPER R.; JASPER M.; FORNARI, A.J.; BLUM, J. Influência da velocidade de deslocamento na semeadura do milho. Engenharia Agrícola, Jaboticabal, v. 26, n.2, p. 520-527, 2006. 
OLIVEIRA, G.C.; DIAS JUNIOR, M.S.; CURI, N.; RESCK, D.V.S. Compressibilidade de um Latossolo Vermelho argiloso de acordo com a tensão de água no solo, uso e manejo. Revista Brasileira de Ciência do Solo, Viçosa-MG, v.27, p.773-81, 2003.

SANGOI, L.; ERNANI, P.R.; BIANCHET, P. Desenvolvimento inicial do milho em função de doses e fontes de nitrogênio aplicadas na semeadura. Revista Biotemas, Florianópolis, v. 22, n. 4, p. 53-58, 2009.

SILVA, J.G.; KLUTHCOUSKI, J.; SILVEIRA, P.M. Desempenho de uma semeadora adubadora no estabelecimento e na produtividade da cultura do milho sob plantio direto. Scientia Agricola, Piracicaba, v.57, n.1, p. 7-12, 2000.

WEIRICH NETO, P.H.; SCHIMANDEIRO, A.; GIMENEZ, L.M.; COLET, M.J.; GARBUIO, P.W. Profundidade de deposição de semente de milho na região dos Campos Gerais, Paraná. Engenharia Agrícola, Jaboticabal, v. 27, n.3, p. p.782-786, 2007. 